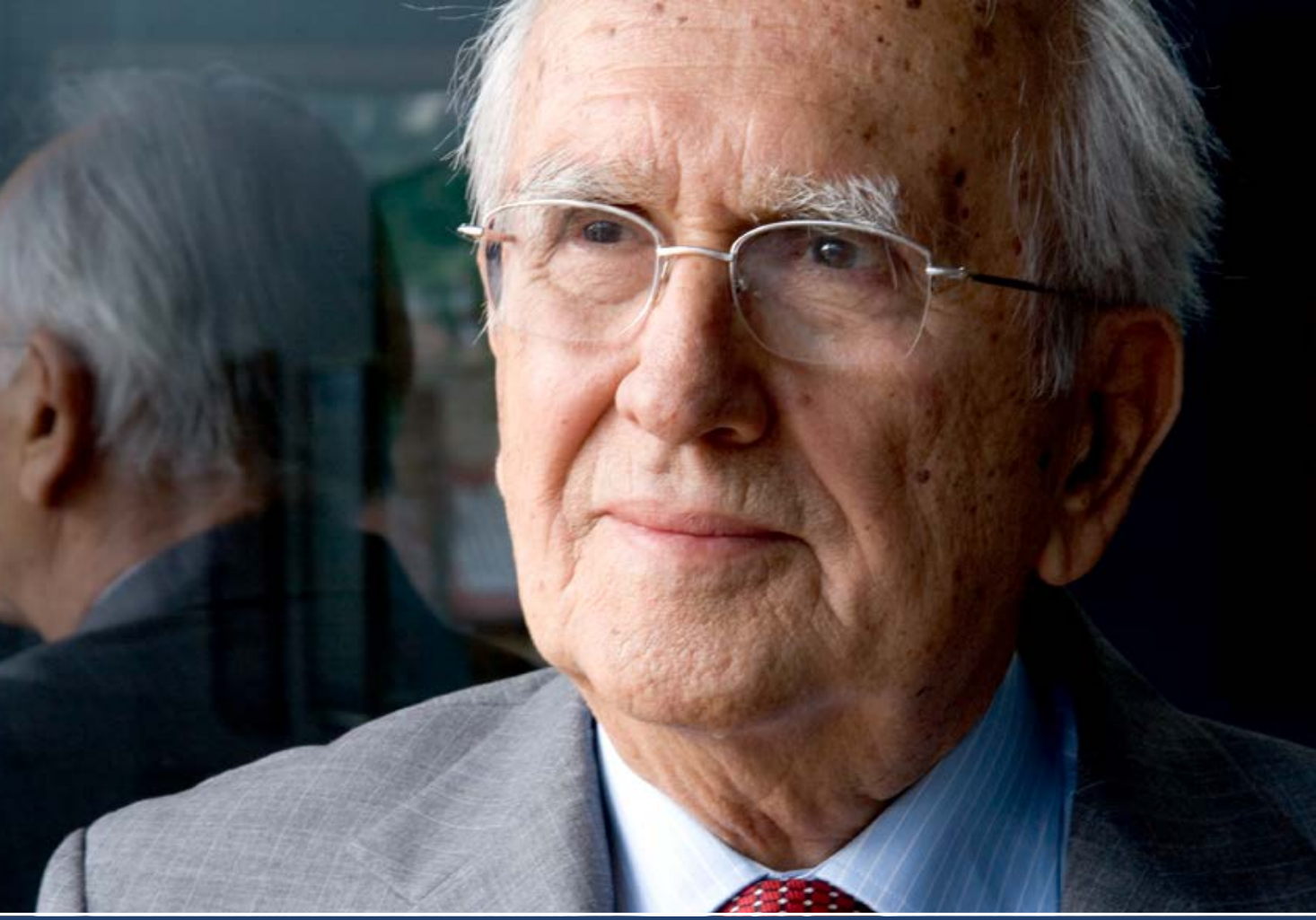

\title{
Adil Zulfikarpašić: od ideologije do identiteta
}

Prof. dr. Zlatko Lagumdžija

21-26.

Adil Zulfikarpašić i liberalne političke inicijative ZBORNIK RADOVA 


\title{
Adil Zulfikarpašić: od ideologije do identiteta
}

\author{
Prof. dr. Zlatko Lagumdžija \\ Ekonomski fakultet Univerziteta u Sarajevu \\ zlatko.lagumdzija@efsa.unsa.ba
}

SAŽETAK: Snage inkluzivnih i ekskluzivnih društava regrutiraju s obje strane tradicionalnog ideološkog spektra. Narodnjački čelnici Njemačke i Mađarske Angela Merkel i Viktor Orban našli su se sukobljeni na branicima inkluzivnog, odnosno ekskluzivnog društva. Isto se desilo i u sukobu na evropskoj Ijevici, gdje je švedski premijer Stefan Löfven branio inkluzivno društvo od svog kolege, slovačkog premijera Roberta Ficoa, kojem je Orban postao „prva politička familija" u odbrani segregiranih društava. Zašto je onda danas potrebno se vraćati na politiku, profil i principe koji su određivali Adila Zulfikarpašića? Bio je Zulfikarpašić čovjek, beg, antifašista, Ijevičar, liberal, demokrata, musliman, Bošnjak, Bosanac, Evropljanin... Imao je svaki od tih identiteta u najboljem i punom značenju tih riječi, kao štoje bio i sve to u isto vrijeme. Kada je ideologija definirala svijet, bio je na strani vrijednosti u koje je vjerovao, a ne onih za koje je u teškim vremenima mogao pomisliti da će biti na pobjedničkoj strani.

KLJUČNE RIJEČr: Adil Zulfikarpašić, inkluzivno društvo, ekskluzivno društvo, globalizacija

Živimo u vremenu koje je bizarna kombinacija emocija kamenog doba, uvjerenja srednjeg vijeka i skoro božanskih tehnologija, mogli smo čuti nedavno, na ovom mjestu, od Geoffreya Saxa. Danas živimo u potpuno drugačijem svijetu od onoga tokom kojeg se Adil Zulfikarpašić, nakon pada Berlinskog zida, vratio u svoju Bosnu i Hercegovinu.

Danas je ekonomska moć planete, mjerena društvenim proizvodom svijeta, četiri puta veća nego tada. Tehnološki smo jači tri puta, dok je količina znanja bar dva puta veća od one koju smo imali na raspolaganju prije tri decenije. Broj Ijudi koji žive u demokratijama zapadnog tipa je udvostručen. Fukuyamin kraj historije nije se desio, kao ni Huntingtonov „neminovni” sukob civilizacija. S druge strane, rastuća ekonomska nejednakost razara države i društva. Prošle godine $1 \%$ najbogatijih povećalo je svoje bogatstvo za $82 \%$ vrijednosti ukupnog novokreiranog globalnog 
bogatstva, dok polovina stanovništva, više od 3,7 milijardi Ijudi, nije dobila ništa od toga.

Tri najbogatija Amerikanca imaju novca kao 160 miliona stanovnika siromašnije polovine Amerike. Uprkos svim dogovorima i upozorenjima, razaranje prirode se nastavlja.

Za tri sata planiranog efektivnog trajanja našeg današnjeg skupa atmosfera će biti „obogaćena” za toplinu jednaku onoj koju bi oslobodila eksplozija od oko 50.000 atomskih bombi bačenih na Hirošimu. Istovremeno, emitirat će se 12 miliona tona $\mathrm{CO}_{2}$ (karbon-dioksida), posjeći će se 4.500 hektara šume, a deset živih vrsta će nestati.

Zašto je onda danas potrebno vraćati se na politiku, profil i principe koji su određivali Adila Zulfikarpašića?

Zašto temeljne vrijednosti za koje se borio i živio mogu biti putokazi i za prosperitetnu zajedničku budućnost?

Zašto iz spoznaje života i vremena u kojem je djelovao možemo, kao i on, biti bliži pravoj strani historije?

Umjesto da živimo u nemjerljivo boljem svijetu, kao i u Bosni i Hercegovini, danas obitavamo u svijetu s desecima novih zidova između, kao i unutar, suverenih država. Rastuća i razarajuća višedimenzionalna nejednakost postaje sve veća prijetnja miru, stabilnosti i prosperitetu svakog društva.

Globalizacija u svim sferama učinila nas je svjesnim svijeta koji dijeli više od 9.80o nacija, Ijudi koji govore preko 7.000 jezika, sa 19 velikih religija i više od 270 vjerskih skupina, organiziranih u 196 suverenih država pod okriljem UN-a, od kojih oko 18o ima najmanje 10\% građana koji su u matematičkom smislu manjina po nekom od svojih identiteta.

Vrijeme ideoloških podjela, tradicionalne Ijevice i desnice, demokratskih i autoritarnih država i društava ustupa pred novim podjelama na temelju identiteta.

Snage inkluzivnih društava zajedničkih vrijednosti i višestrukih identiteta kao bogatstva danas se konfrontiraju snagama segregiranih društava i ekskluzivnih identiteta, koje različitosti doživljavaju kao slabosti kojih se treba riješiti. 
Život Adila Zulfikarpašića odvijao se kao velike priče, čije refleksije predstavljaju jasan nauk u suočavanju s vremenom velikih promjena koje je pred nama.

Priča o ideologiji, socijalnoj pravdi, antifašizmu, liberalizmu, demokratiji, pravdi i slobodi ograničenoj slobodom drugih.

Priča o identitetu, plemenitosti, Bosanskim muslimanima, Bošnjacima, Bosni i Hercegovini kao inkluzivnom društvu zajedničkih vrijednosti i bogatstvu višestrukih identiteta.

Priča o čovjeku koji je radio i živio ono u što je vjerovao, a ne ono što bi mu donosilo slavu, novac ili moć po cijenu kompromisa s ličnim uvjerenjima. Priča o čovjeku koji se ponosno, sadržajno i s uzajamnim uvažavanjem družio i radio s krunisanim glavama i državnicima, akademicima i biznismenima, kao is mladim ili „običnim” Ijudima, u mjeri u kojoj je u njima vidio moralnu ili kreativnu vrijednost.

Priča o čovjeku koji je odlučivao na osnovu vrijednosti u koje je vjerovao, a ne cijene koju je trebalo platiti.

Priča o čovjeku koji je odlučivao na osnovu toga kako će se te odluke valorizirati za desetak godina, a ne za desetak dana.

Priča o čovjeku koji se uvijek htio okružiti Ijudima od kojih ima šta čuti, jer je znao da će u protivnom završiti okružen Ijudima koji nemaju šta reći. Priča o čovjeku koji je poštivao svoju i tuđu prošlost, znao vrijednosti tradicije i kulture, dok je s istim žarom usvajao novo, dijelio iskustva sa drugima, vjerujući u snagu argumenata zasnovanih na znanju i stalnom učenju.

Na kraju, kao i na početku, to je priča o čovjeku koji je uvijek bio na pravoj strani historije, i kada je pobjeđivao i kada je gubio. Zato što je mislio, govorio i radio ono u što je vjerovao, a ne zato što nije imao drugog izbora - a sve to je činio, prije svega, vođen plemenitim, a ne pragmatičnim vrijednostima.

Za liderstvo s vizijom i vrijednostima, za koje je imao strast, nije mu bilo teško devet puta pasti i deset puta se ponovo dići i nastaviti putovanje, kako za ideologiju u koju je vjerovao tako i za identitete koje je imao. Kada je ideologija definirala svijet, bio je na strani vrijednosti u koje je vjerovao, a ne onih za koje je u teškim vremenima mogao pomisliti da će biti na pobjedničkoj strani. 
Danas, kada identiteti i odnos prema njima određuje politike širom svijeta, vrijedi se vratiti Adil-begovoj ideji Bosne i Bošnjaka kao paradigmi inkluzivnog društva zajedničkih vrijednosti i bogatstva višestrukih identiteta.

Adil Zulfikarpašić je bio čovjek, beg, antifašista, Ijevičar, liberal, demokrata, musliman, Bošnjak, Bosanac, Evropljanin... Imao je svaki od tih identiteta u najboljem i punom značenju tih riječi, kao što je bio i sve to $u$ isto vrijeme.

Upoznao sam ga kao čovjeka koji nikada to nije razdvajao niti je htio biti nešto od toga najviše, kao čovjeka koji je bio ponosan na svaki od svojih višestrukih identiteta. Samo su ga drugi, ne htijući, znali natjerati da nekada bude nešto od toga najviše i to tako što bi mu napali ili negirali nešto od onoga što je bio.

Danas, kada je broj izbjeglih i raseljenih osoba u svijetu (68,5 mil.) nadmašio broj stanovnika Francuske (67,5 mil.) ili Kanade, Australije i Norveške zajedno (37, 25 i 5 mil.), kada je svake dvije sekunde, u nekom sukobu, jedna osoba protjerana i raseljena iz svog doma, kada širom svijeta azil traži onoliko Ijudi koliko danas živi u Bosni i Hercegovini, kada su apatridi (1o mil.), Ijudi bez državljanstva, tri puta brojniji od nas koji smo upisani u knjigu državljana Bosne i Hercegovine - populisti i zagovornici segregiranih društava branu svojim planovima vide u socijalno-liberalnim politikama i promotorima inkluzivnih društava zajedničkih vrijednosti.

Migrantska kriza je pokazala kako se snage inkluzivnih i ekskluzivnih društava regrutiraju s obje strane tradicionalnog ideološkog spektra. Narodnjački čelnici Njemačke i Mađarske Angela Merkel i Viktor Orban našli su se sukobljeni na branicima inkluzivnog, odnosno ekskluzivnog društva. Isto se desilo i u sukobu na evropskoj Ijevici, gdje je švedski premijer Stefan Löfven branio inkluzivno društvo od svog kolege, slovačkog premijera Roberta Ficoa, kojem je Orban postao „prva politička familija” u odbrani segregiranih društava.

Neki današnji Crveni Beg, Adil-begov Bošnjak ili sin vjekovne Bosne ili pravi musliman, partizan i liberal, čovjek bogat višestrukim identitetima je onaj koji je na istoj strani s crvenim Löfvenom i plemenitom Angelom.

U vremenu koje živimo, možda više nego ikada prije, vrijedi se podsjetiti na to s koliko se digniteta Adil-beg nije obazirao na drugorazredne igrače, kojima je toliko valjao, a od njih samo niske udarce dobijao. Znao je da se loši Ijudi često najgrublje i najžešće obračunavaju s onima koji su bolji od njih, s Ijudima kakvi bi i sami bezuspješno željeli postati. 
Crveni Beg, drug i gospodin, odlično je znao da će nas to još dugo pratiti i da je prezir najbolji lijek protiv takvog primitivizma i zla. Ali to njegovo iskustvo je još jedna velika priča koja ne govori toliko o njima, već dodatno svjedoči o njegovoj, Adil-begovoj veličini, kao i o boljim melecima naše prirode.

Danas sam s vama podijelio dio onoga najvrednijega što sam stekao u druženjima s Adilom Zulfikarpašićem. Na ovom tragu se može nastaviti u mjeri u kojoj imamo snagu volje da poslije svakog pada nešto naučimo, podignemo se i nastavimo dalje, vođeni vizijom i vrijednostima koje nas čine boljim Ijudima. Na dugom i krivudavom putu koji pravimo kako bi Ijudi po njemu dostojanstveno koračali.

Iza nas su stare bitke. Pred nama su novi izazovi u vremenu ubrzanih promjena. S nama su naša uvjerenja i volja da ih pretvaramo u stvarnost. S Ijudima s kojima dijelimo zajedničke snove.

Imam sreću, srce i pamet da sam na istom putu sa Crvenim Begom Adilom Zulfikarpašićem.

Od vizije do uvjerenja.

Od ideologije do identiteta. 


\section{Adil Zulfikarpašić: From Ideology to Identity}

ABSTRACT: The forces of inclusive and exclusive societies are recruiting on both sides of the traditional ideological spectrum. The people's leaders of Germany and Hungary, Angela Merkel and Viktor Orban, found themselves in conflict on the defences of an inclusive and exclusive society, respectively. The same happened in the conflict in the European Left, where Swedish Prime Minister Stefan Löfven defended an inclusive society from his counterpart, Slovak Prime Minister Robert Fico, to whom Orban became the "first political family" in defence of segregated societies. Why, then, is it necessary to- day to return to the politics, profile and principles that determined Adil Zulfikarpašić? Zulfikarpašić was a man, a bey, an anti-fascist, a leftist, a liberal, a democrat, a Muslim, a Bosniak, a Bosnian, a European... He had each of these identities in the best and full sense of those words, as he was at the same time all that altogether. When ideology defined the world, he was on the side of the values he believed in, not those he could have thought in difficult times that would be on the winning side.

KEYWORDS: Adil Zulfikarpašić, inclusive society, exclusive society, globalization 